\title{
A Virgin Galactic SpaceShipTwo szuborbitális ürrepülőgépének katasztrófája
}

K egyetlen verseny zajlik a magán ürhajózás terén. Sok-sok milliárd dollár megszerzése a cél. A Virgin Galactic Vállalat SpaceShipTwo szuborbitális űrrepülőgépének 2014. október 31-én történt végzetes balesetét egyértelműen a másodpilóta hibája okozta. A kaliforniai Mojave-sivatagban végrehajtott kísérleti repülés során a másodpilóta túl korán aktiválta a kereskedelmi ürrepülőgép szárnyvégnyitó rendszerét. „Ám a tervezők sem végeztek kellően alapos munkát, amikor figyelmen kívül hagyták a pilóták egyikének részéről történő szabotázs választhatóságát" - fogalmazzák meg jelentésükben a Nemzeti Közlekedésbiztonsági Bizottság szakértői.

A Nemzeti Közlekedésbiztonsági Bizottság (NTSB) nyomozását Cristopher Hart vezette. Az általa vezetett csoport feladata annak kiderítése volt, vajon - az előzetes feltételezéseknek megfelelően - ténylegesen emberi hiba okozta-e a Virgin Galactic űrrepülőgépének katasztrofális pusztulását. Az ürrepülőgépet építtető vállalat is felállította a maga nyomozóbizottságát, s igyekezett a lehető legszorosabban együttműködni a szövetségiekkel. Emellett határozottan arra kérte a szövetségieket, segítsenek meghatározni számukra azt az irányt, amely megmutatja, hogy „miként lehet megvédeni a SpaceShipTwo (2-es számú ürhajó, a továbbiakban: SS2) ürrepülőgépet attól, hogy emberi szándék vagy hiba ilyen katasztrofális következményeket okozzon". A bizottságot vezető Christopher Hart várakozásának adott hangot, szavait idézve: „Reméljük, munkánk eredményeként a jövőben sikerül megakadályoznunk az ehhez hasonló súlyos balesetek bekövetkeztét."

A Virgin Galactic SS2 űrhajóját úgy tervezték, hogy két pilótát és hat utast szállít szuborbitális ürrepülésre. Az utazás ára fejenként 250.000 dollár. Útjára a WhiteKnightTwo repülőgép hasa alól startol, kb. 15 km-es magasságból. A hangsebességet 8 másodpercen belül éri el. A hajtómüve 70 másodpercig működik, ezután kikapcsolják. A tehetetlenségi erő miatt az űrhajó tovább emelkedik, egészen $100 \mathrm{~km}$ fölé, ahonnan aztán siklórepüléssel tér vissza. Szárnyának kialakítása lehetővé teszi, hogy bármilyen szögben képes legyen belépni a sűrű légkörbe.

2014. október 31-én - a negyedik meghajtásos próbarepülése alkalmával - az első SS2 darabjaira hullott a kaliforniai Mojave-sivatag fölött, roncsai pedig mintegy $8 \mathrm{~km}$ átmérőjű területre szóródtak szét a Koehn-tó környékén.
Michael Alsbury veterán berepülőpilóta, aki már korábban is repült az SS2 ürhajóval, életét vesztette a baleset során. Peter Siebold pilóta súlyosan megsérült, amikor katapultülését aktiválta, ám végül ejtőernyővel földet ért és túlélte a történteket.

Az NTSB nyomozói kiderítették, hogy a baleset akkor következett be, amikor Alsbury túl korán kapcsolta be az SS2 szárnyvég-forgató mechanizmusát, akkor, amikor a gép még csak 0.8 Mach sebességgel száguldott, $\mathrm{s}$ nem pedig 1,4 Mach sebességgel, miként azt a repülési terv előírta. A repülésről készült videón jól látható, hogy a szárnyvégek teljesen váratlanul, a repülési fázisnál használt állásból elkezdenek átfordulni a fékezési állásba.

Az SS2 szárnyának hátsó része, a farka, vagy más szóval a „tollazata”, páros felépítésű, állásszöge változtatható, „zárt” állapotban belesimul az ürhajó deltaszárnyának síkjába, „nyitott” állapotban arra nagyjából $60^{\circ}$-os szöget zár be. Az űrrepülőgép a tollazatát $25 \mathrm{~km}$-es magasságban nyitja ki, így lép be a sűrű légkörbe - a „tollazat” ugyanis segít az úrhajó stabilizálásában -, és a hátsó szárny ezen állapota meg is marad a repülés végéig. A hajtómű működésének idején zárt állapotban van, így adva az űrrepülőgépnek további stabilitást. Amikor Alsbury túlságosan korán nyitotta a szárnyakat (véletlenül ilyesmi nem fordulhat elő), erős turbulencia keletkezett, olyannyira erős, ami már meghaladta az SS2 ürhajó biztonsági stabilizáló mechanizmusának képességét, és ennek következtében az ürhajó darabjaira hullott.

Az NTSB hatalmas mennyiségú adatot - többek között a telemetrikus adatokat, valamint számos kabinban készült és külső videófelvételt - vizsgált át a balesettel kapcsolatban, mielőtt meghozta döntését.

\section{A baleset elemZése}

Az SS2 negyedik hajtóműves repülése - amely a PF04 jelzést viselte - a Virgin Galactic szuborbitális ürrepülőgépének legnagyratörőbb vállalkozása volt. Az előzetes tervek szerint a hajtómű, az előző kísérleti repülésekhez képest kétszer annyi ideig, 38 sec-en át működött volna. Ily módon az űrrepülőgép kétszeres hangsebességig gyorsult volna, az elérni kívánt magasság pedig kb. $40000 \mathrm{~m}$ volt.

ABSTRACT: On 31 October 2013, the suborbital spacecraft SpaceShipTwo owned by the private spaceflight company Virgin Galactic had a fatal accident over the Mojave desert in California. This article deals with the operational, technical and design conditions of the accident and, in addition, the status of building of the second spacecraft SpaceShipTwo.

KEY WORDS: private spaceflight, the company Virgin Galactic, spacecraft SpaceShipTwo 


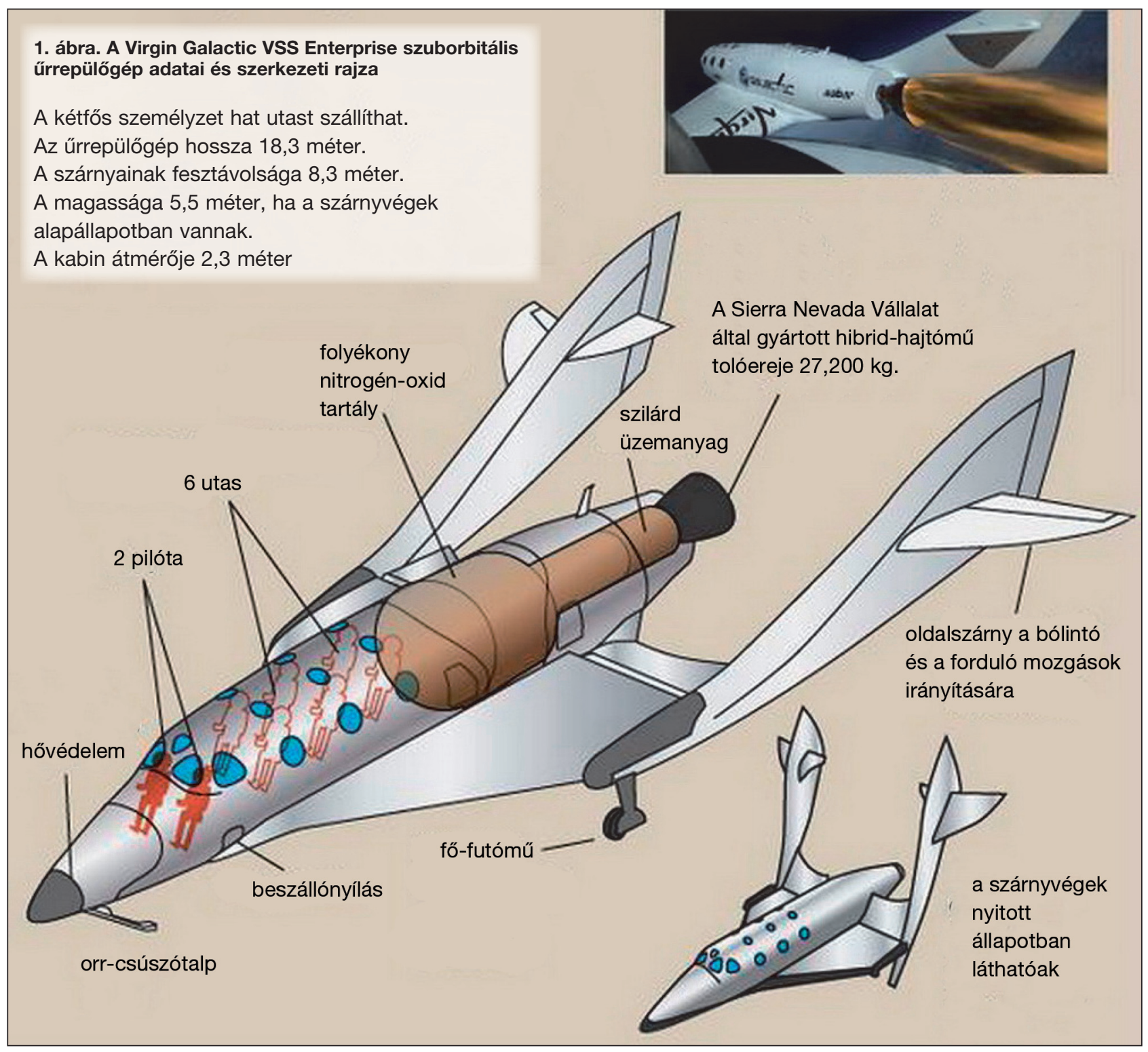

A kísérlet egyben egy új szilárd hajtómű próbája is volt, a korábbi repüléseknél használt gumi-alapanyagú helyett egy nejlon alapanyagú hajtóművet próbáltak ki.

A repülés hónapokat késett. „A hajtómű problémája miatt a PF04 repülésének időpontját számos alkalommal elhalasztották." Ez derült ki a Virgin Galactic által az NTSB részére eljuttatott tucatnyi dokumentumból, valamint a bizottság által végrehajtott meghallgatások során. A repülést már az előző, sikerrel végrehajtott 2014 januári próba után, a meglévő hajtómű leghosszabb üzemidejű próbájaként kezdték el tervezni. „A folyamatos problémák miatt azonban a munka többször félbeszakadt, és csak júniusban folytatódott" - tudatta a vállalat.

2014. május végén a Virgin Galactic bejelentette, hogy áttér a nejlon, azaz a poliamid alapú üzemanyag használatára, ami miatt az űrhajón további változtatásokat kellett végrehajtani. (Néhány változtatást, például az ürhajó szárnyába épített újabb tartályt, a nyilvánosságra hozott dokumentumokban kitakartak.) „A változtatások és a hajtómú további fejlesztései, valamint a minősítési üzemeltetések májustól egészen a 2014 októberében végrehajtott PF04 küldetésig zajlottak" - tudatják a dokumentumok.
A PF04 repülést eredetileg október 23-ra tervezték, azonban elhalasztották, mert az űrhajóra ható terhelésekre vontakozóan további adatelemzésekre volt szükség. November 6-án az NTSB nyomozóinak kérdésére Matt Stinemetze, a Scaled Composit programigazgatója az SS2 és a WhiteKnightTwo gépeket illetően elmondta, úgy érezte, a Virgin Galactic nyomást gyakorol rá a repülés végrehajtása érdekében. Emiatt „némileg ideges volt”, ahogy a terhelésre vonatkozó kérdések korábbi, nem teljes körű kivizsgálása miatt is. Késésben voltak ezzel a munkával, ezért úgy vélte, az ürrepülőgép még nincs teljesen kész. „100\%-os támogatást kapott abban a tekintetben, hogy leállítsa a repülést, ha úgy érzi, nem áll minden készen" - összegezte a vele folytatott beszélgetés tapasztalatait az NTSB.

A PF04 kísérletet végül október 23-ról október 31-re halasztották, a Virgin Galactic és a Scaled Composit ezt az időt „városházi” találkozóra használta. A találkozón, a Scaled Composit tisztségviselői elmondták, megtárgyalták a Virgin Galactic vezérigazgatójának a terhelésre vonatkozó problémákkal kapcsolatos kérdését, aki azzal fordult hozzájuk, hogy: „Mire van még szükség?”. A négyórás találkozót „eredményesnek” ítélték a Scaled Composit szak- 


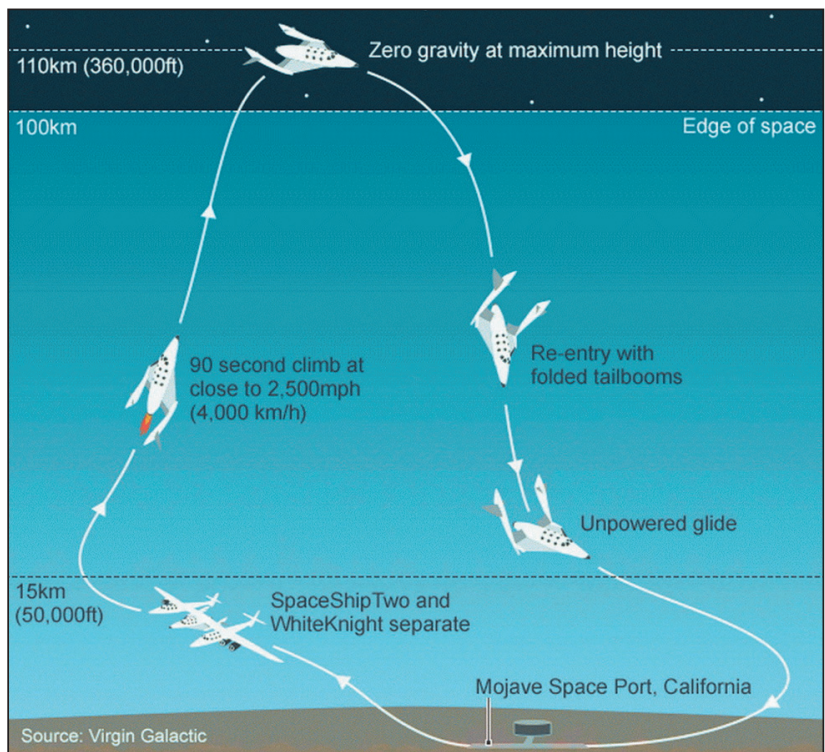

2. ábra. A SpaceShipTwo repülési profilja - amikor majd utasokat is szállít. A levegöbe a WhiteKnightTwo hordozógép hasa alatt indul. $15 \mathrm{~km}$-es magasságban leválik, majd 90 másodpercre beindítja a hajtómúvét. Kb. $110 \mathrm{~km}$-es magasságig kapaszkodik fel, ahonnan siklórepülésben tér vissza, a súrübb légkörben nyitott szárnyvégekkel ér földet a kaliforniai Mojave Ürkikötőben

emberei, ám a PF04 kísérlettel kapcsolatban semmiféle további halasztás nem történt.

„Az egyik kérdés, ami felmerült - emlékszik vissza a Scaled Composit alelnöke, Cory Bird -, az SS2 szárnyforgató rendszerének aktiválását lehetővé tévő zárszerkezet volt. Erről a szerkezetről csak nagyon kevés szó esett" idézte fel az eseményeket az NTSB nyomozójának, Mr. Whitesidesnak a kérdésére.

3. ábra. A SpaceShipTwo méretarányos rajza a Szojuz ürhajóhoz és az Ansari Xprize-győztes SpaceShipOne ürrepülögéphez képest

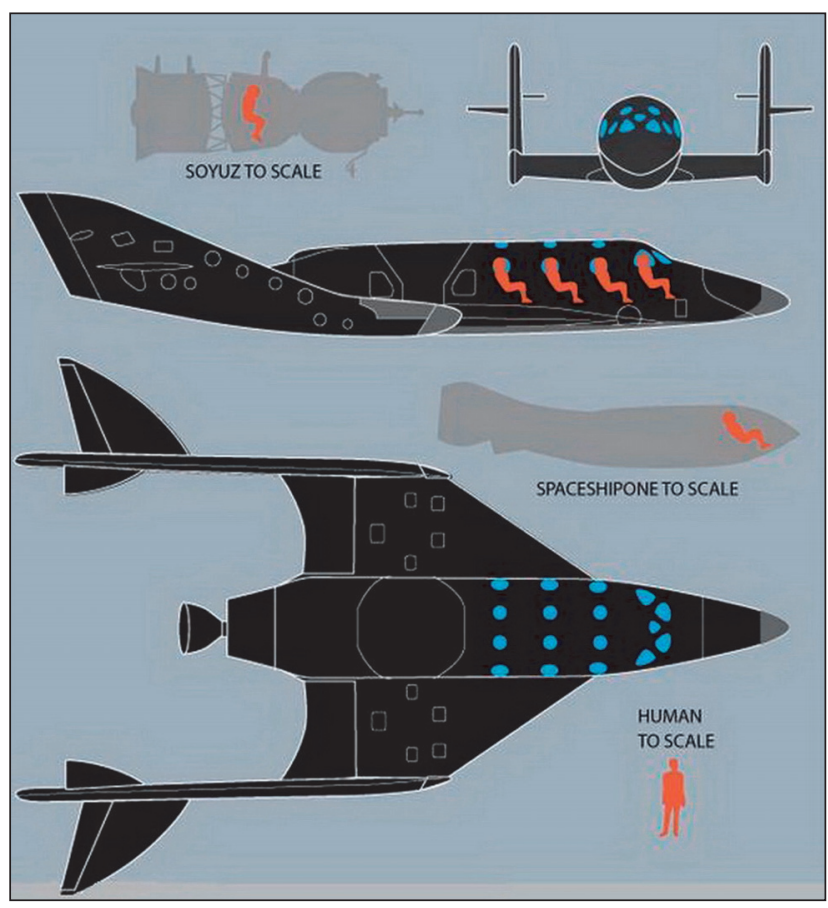

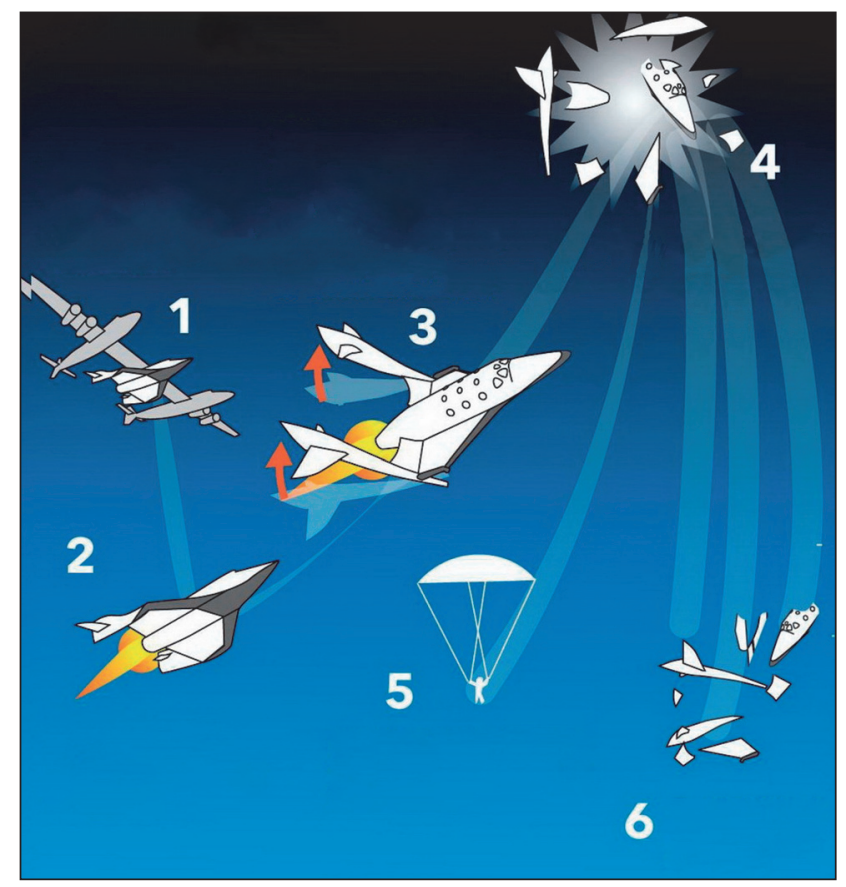

4. ábra. A balul végződött kísérleti repülés fázisai

1. A WhiteKnightTwo szállítógép hasa alá rögzítve látható a SpaceShipTwo ürrepülőgép. 2. A leválás rendben végbemegy, az ürrepülőgép bekapcsolja hibrid hajtóművét. 3. Kilenc másodperccel a hajtómú indítását követően a szárnyvégek váratlanul mozgásba lendülnek, és felveszik a fékezési állapot szögét.

4. Két másodperccel később az ürrepülőgép darabjaira kezd hullani. 5. Peter Siebold pilóta sikeresen katapultál és földet ér. 6. A másodpilóta életét veszti a balesetben

A zárszerkezet kritikus alkotója volt az SS2 szárnyforgató rendszerének, amelynek feladata a visszatérés során az űrhajó ikerszárny-végeinek $60^{\circ}$-kal való elfordítása, ily módon növelve az űrhajó stabilitását és kormányozhatóságát. A zárak feladata a szárnyvégek rögzítése alapállapotban, különösen akkor, amikor nagyjából az 1 Mach tartományban, azaz a hangsebesség környékén, az aerodinamikai erők emelőhatást fejtenek ki rájuk. A Scaled Composite mérnökei felismerték, hogy a szárnyvégek viselkedése abban a fázisban egyenesen „katasztrofális” volt. Fontos volt tehát, hogy a szárnyvégeket rögzített állapotban tartsák a hajtómű működésének kezdeti időszakában, vagyis amikor az SS2 űrrepülőgép a hangsebesség közelében jár.

$A z$ űrrepülőgép biztonságának növelése érdekében a szárnyvégeknek tehát zárt állapotban kell lenniük a hajtómű működése idején. Viszont ha a visszatérés során a szárnyvégek zárt állapotban maradnának - például azért, mert a nyitószerkezet nem működik -, az a helyzet az SS2 számára ugyancsak végzetes lenne. A pilótának kell tehát kioldania a zárszerkezetet a transzszonikus tartományon túl, hogy ha esetleg a zárszerkezet beragadna, a repülést félbe lehessen szakítani kellően alacsony sebességen ahhoz, hogy a biztonságos leszállás még kivitelezhető legyen a szárnyvégek kinyitása nélkül is.

A Scaled Composite mérnökei azon az állásponton voltak, hogy a zárszerkezetet már 1.2-szeres hangsebességnél ki lehet nyitni, ám hagytak némi mozgásteret a másodpilóta számára, hogy az 1.4-1.5 Mach tartományban is végrehajthassa ezt a műveletet. Ekkor azonban már figyelmeztető jelzés jelenik meg a műszerfalon a zárak továbbra is zárt állapotáról, a pilótáknak pedig ez esetben le kell kapcsolni a hajtóművet, és félbeszakítani a repülést. Így 


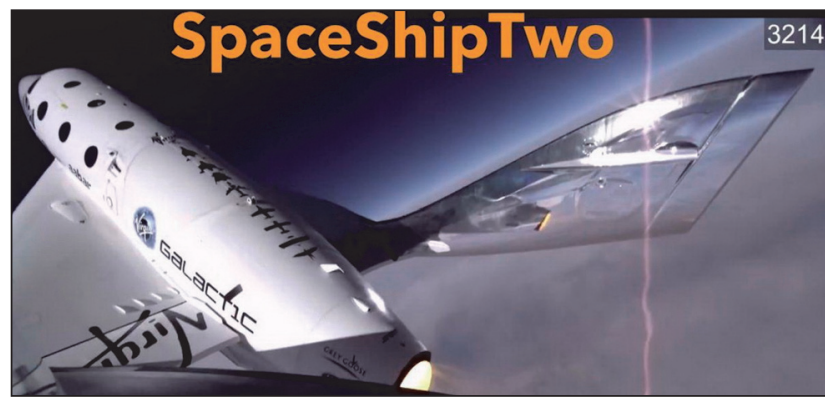

5. ábra. A Virgin Galactic kísérleti ürrepülőgépe, a VSS Enterprise, 13 másodperccel hajtómúvének begyújtását követően, 2014. október 31-én megsemmisült. A fedélzeti kamera felvétele néhány pillanattal a katasztrófa bekövetkezte előtt készült

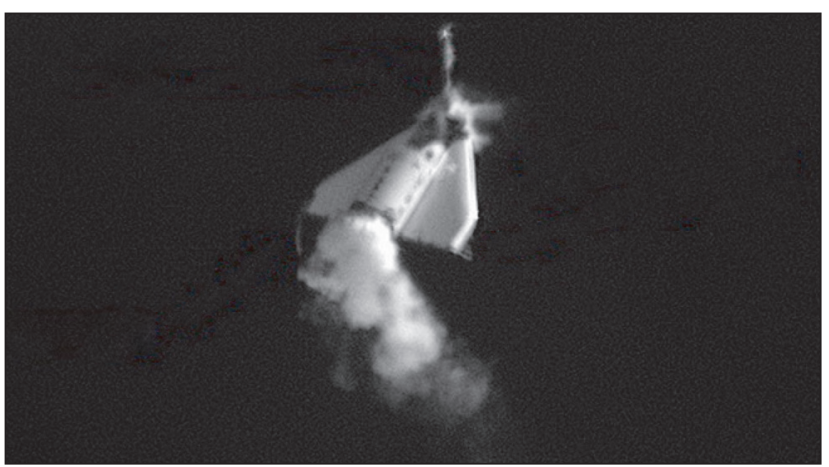

7. ábra. Az ûrsikló darabjaira hullik. Leszakadnak a szárnyvégek, elszabadulnak a különböző kábelkötegek, láthatóvá válik a vázszerkezet
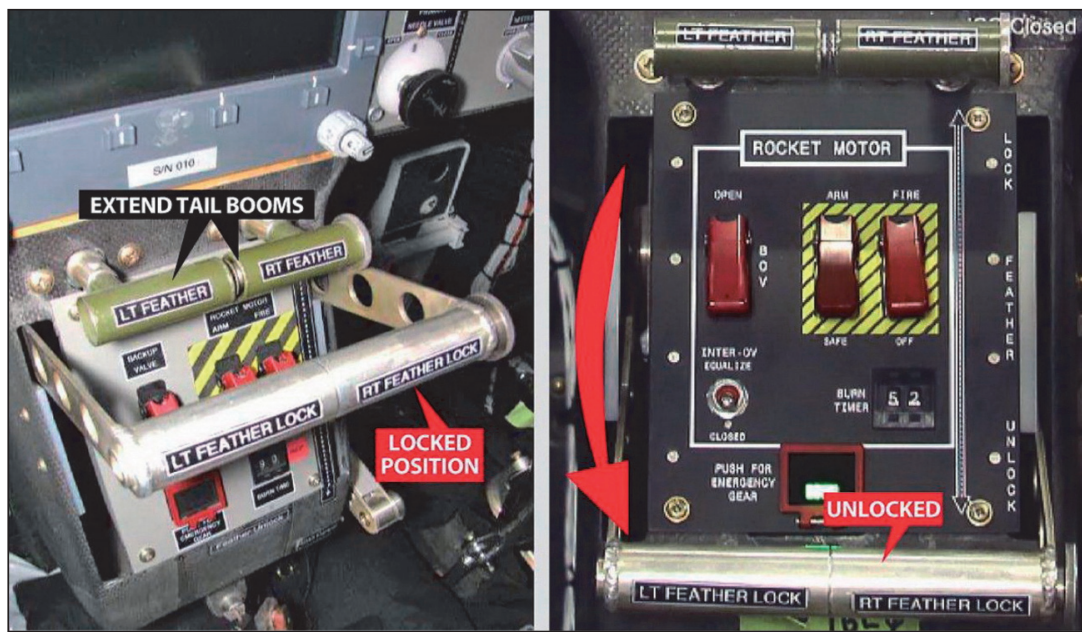

6. ábra. Bal oldalon: a szárnyvégek nyitószerkezete zárt állapotban, a két fogantyút egy kar takarja, hogy a pilóta véletlen mozgása ne hozhassa müködésbe azokat önmagát, miközben az űrhajó a WhiteKnightTwo hasa alatt függött. Semmi olyan nem történt, ami egy kísérleti repülés esetén ne lett volna megszokott.

A repülést megelőzően Michael Alsbury másodpilótának különböző eljárások sorozatát kellett megtanulnia, amelyek végrehajtása a hajtómű működésének idején az ő feladata volt. Tekintettel az események gyors folyamatára, a Scaled Composit szakemberei arra a következtetésre jutottak, hogy a hagyományos, „ellenőrző listás” megoldás ez esetben nem elég hatékony, nem egy szokásos „kérdés-válasz rendszer” van tehát, ahol a pilóta szóban adja ki a parancsot és a másik fél megerősíti azt. Alsbury feladata volt, hogy a hajtómü működése idején hangosan bemondja azt az állapotot, amikor az ürhajó eléri a 0.8 Mach sebességet, azaz jelentse,

kellett volna eljárni a PF04 kísérlet során, ha a szárnyak továbbra is zárt állapotban maradtak volna 1.8 Mach esetében is, amely esetben a maximális sebességet 2.0 Machra tervezték. Ez volt az első eset, amikor a szárnyvégek a hajtómű működésének teljes ideje alatt zárt állásban maradtak volna, vagyis olyasmit szerettek volna végrehajtani, amit a korábbi kísérleti repülések során egyetlen alkalommal sem.

Miközben a szárnyvégek mozgatásának témája felmerült a városházi találkozón, nem tủnt úgy, hogy ez az ügy bármi módon szerepet kapna a repülés során. A terhelésekre vonatkozó elemzésekkel elkészültek, és úgy tủnt, immár semmi sem gátolja az október 31-i indulást. A kísérleti repülésben résztvevők, köztük a katasztrófa során életben maradt Pieter Siebold pilótát is, semmiféle rendellenességről nem tettek említést sem az előkészületek, sem pedig a WhiteKnightTwo hordozó-repülőgépről, délelőtt 10.07 perckor (keletei parti idő) történő leválásig a - Mojave Repülő- és Ürkikötő légterének északi részén. Bár nem volt minden problémamentes, a felszállást késleltetni kellett, ugyanis a hajtómű nitrogén-oxidja még nem érte el a megfelelő hőmérsékletet, a széllel kapcsolatban is aggodalmak merültek fel, az SS2 fedélzeti számítógépe pedig véletlenszerūn újraindította

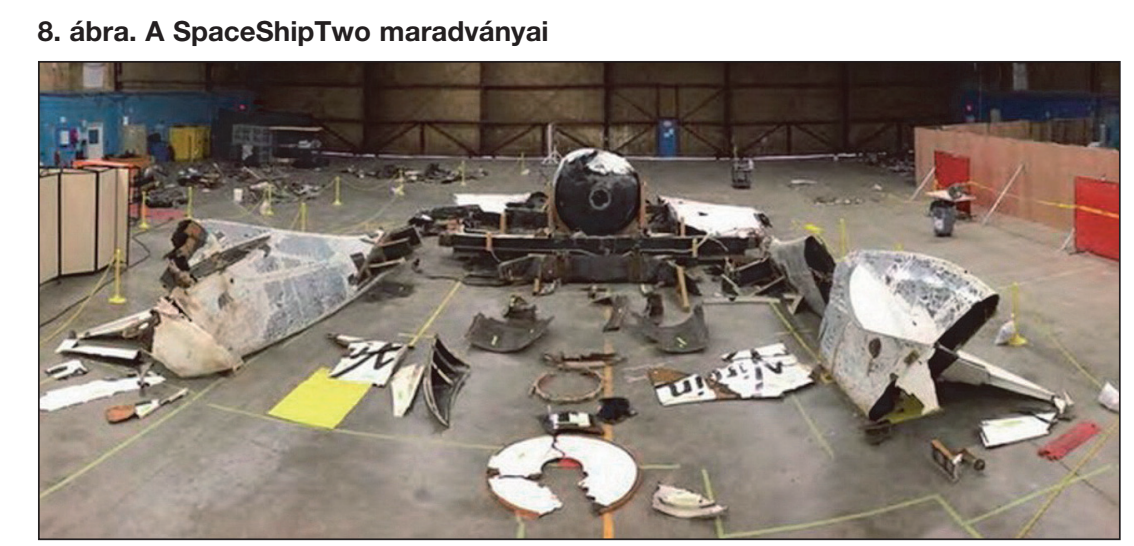

hogy közelednek a hanghatárhoz - vagyis a hangrobbanás bekövetkeztéhez, amikor is számos vibráció éri az ürrepülőgépet, miközben átlépi a hanghatárt. Jelentenie kellett a stabilizátorok szögállását; továbbá, 1.4 Mach sebességnél ki kellett oldania a zárszerkezetet.

10:07 perc 26,91 másodperckor elhangzott Alsbury jelentése: „0,8”, utalva arra, hogy néhány másodperccel az SS2 hajóművének beindítását követően, az ürrepülőgép a hangsebesség átlépéséhez közelített. Az NTSB szakemberei által a baleset után elvégzett próbákból az derült ki, hogy az ürhajónak még 15 másodperc kellett volna ahhoz, hogy elérje az 1,4 Mach sebességet, amikor Alsburynek nyitnia kellett volna a szárnyvégeket. 
